\title{
ISLAMIC LOCAL AWAKENING: STUDY OF MUHAMMADIYAH RENEWAL AS THE RISE OF ISLAMIC EDUCATION IDENTITY IN SOUTH SUMATERA
}

\author{
Arif Rahman \\ Universitas Ahmad Dahlan \\ Jl. Ringroad Selatan, Banguntapan, Indonesia \\ Email: arif.rahman@pai.uad.ac.id \\ Received: 01, 2019. Accepted: 07, 2019. Published: 07, 2019.
}

\begin{abstract}
The purpose of this study is to construct the dynamics of Muhammadiyah education in South Sumatera which is undergoing a phase called the local awakening. Such conditions occur after social, political and religious relations have struggled during the development of Muhammadiyah education there, which also helped encourage the renewal of overall Islamic education in South Sumatera. This study is a qualitative study with a social history approach. Data in the form of historical facts related to this research are collected through library and documentation techniques. The results of this study indicate that the construction of Muhammadiyah education as an identity for Islamic education in South Sumatera actually happened due to factors of Islamic renewal which occurred intensively in rural areas (periphery) that experienced a process of negotiation and integration in the social community. So that the renewal of Islam carried out by the modernist movement there actually appeared in rural areas not in urban areas as happened in other regions in Indonesia.
\end{abstract}

Keywords: Islamic Education, Muhammadiyah, Local History

\begin{abstract}
ABSTRAK
Tujuan penulisan artikel ini untuk mengkonstruksi dinamika pendidikan Mubammadiyah di Sumatera Selatan yang mengalami fase disebut dengan kebangkitan local. Kondisi demikian terjadi setelah relasi social, politik dan keagamaan mengalami pergumulan selama perkembangan pendidikan Mubammadiyab di sana, yang turut pula mendorong terjadinya pembaharuan pendidikan Islam secara keseluruban di Sumatera Selatan. Studi ini merupakan penelitian kualitatif dengan pendekatan sejarah social. Data-data berupa fakta-fakta sejarah terkait penelitian ini dikumpulkan melalui teknik kepustakaan dan dokumentasi. Hasil penelitian menunjukkan bangunan konstruksi pendidikan Muhammadiyah sebagai identitas pendidikan Islam di Sumatera Selatan, justru terjadi karena faktor pembaharuan Islam yang secara intensife terjadi di wilayah pedesaan (pinggiran) yang mengalami proses negosiasi dan integrasi dalam sosial masyarakat. Sehingga pembaharuan Islam yang dilakukan oleh gerakan modernis di sana justru muncul di daerah pedesaan bukan di perkotaan seperti yang terjadi di wilayah lainnya di Indonesia.
\end{abstract}

Kata Kunci: Pendidikan Islam, Muhammadiyah, Sejarah Local

\section{INTRODUCTION}

The development of Islamic education in South Sumatera over a period of time has its own style. The renewal of education that took place in South Sumatera was carried out by the Kaum Tuo (Islamic traditionalists) and Kaum Mudo (Islamic modernists), especially in the other parts of Sumatera. It was the Kaum Tuo who played a major role in the renewal. This is different from the case in South Sumatera, Ismail in his findings explained that the renewal that occurred in the South Sumatera area was the opposite. He saw that the movement of Islamic education in South Sumatera was more likely to be initiated by the efforts of the younger generation, so that the stretch of style that grew showed that the renewal of Islamic education in Palembang was departed from the Kaum Mudo movement (Sukardi, 2013). This is in line 
with the initiative of young Muhammadiyah leaders (Formichi, 2012) in initiating Islamic education especially among Muhammadiyah (Almanak Muhammadiyah, 1936). The dynamics of Muhammadiyah education in South Sumatera began with the arrival of Minangkabau traders (Noer, 1996) who introduced Muhammadiyah to several regions in Sumatera until they arrived in Palembang.

Speaking about Muhammadiyah development, Nakamura (1983) as quoted by Farid studied this issue. He assessed that there are three important values in Muhammadiyah education; First, Muhammadiyah education has succeeded in arousing national consciousness patterned in Islam. Second, its education has succeeded in becoming an effective tool for spreading the ideology of Islamic reform. Third, it plays a major role in spreading the practical knowledge of modern science. Muhammadiyah education is another option for people in choosing religious schools. The mission of Muhammadiyah itself brings the idea of renewal, also because of its consistency in the path of education (Setiawan, 2016).

Muhammadiyah has always been in a situation to deal with national politic for its educational movement. Peacock (1978) itself suggests the success of Muhammadiyah education, precisely because of the form of the statement of separation from politics, even though it is involved in politics at a certain level (Peacock, 2016). This organization serves as an independent Islamic organization along with other Islamic organizations who opposed Dutch colonial rule. This organization concentrates on welfare, education and health issues by avoiding explicit participation in politics. Through social education services as agents of social change, Muhammadiyah developed into one of the main nationalist actors (Abuza, 2006).

The socio-political changes in South Sumatera to some extent have shaped Muhammadiyah phases of the development for educational movement. Its schools and madrasas on its journey experiencing what is called "local renewal". That is besides it follows the flow of development from the land of Java, but it also responds to local and socioreligious changes in the South Sumatera area.

Considering the various explanations above, the research on the history of Muhammadiyah education in the periphery is still under research not to mention it as marginalized. Most studies reported reviews of Muhammadiyah literature in central Java. The issue of Muhammadiyah educational movement in periphery is a little overlooked by the attention of many researchers and historians. They are still focused on the center of Muhammadiyah development in Java, especially in Yogyakarta. Moreover, it is as if the dynamics of the development of the Muhammadiyah in the periphery are always in harmony with the rhythms of its development in other regions. In fact, this does not always happen in Palembang and other South Sumatera regions. Interestingly, the history of Muhammadiyah in the local area and the periphery has its own characteristics and dynamics. The lack of research on Muhammadiyah education in the periphery or village context, has been identified and it requires further investigation.

Muhammadiyah education in South Sumatera has gone through the negotiation phase of religious understanding and its role in social change at that time. This organization has a manifestation of the identity of Islamic education in South Sumatera and it needs to be emphasized and constructed. This organization has undergone Ideological relations, religious understandings, society and the socio-political situation that makes it struggle to deal with them. This could be seen as the building of Muhammadiyah education construction and it reflected as a model for the rise of Islamic education identity at that time.

Several studies related to this issue has been reported. Those studies investigate the reality of religious conflict in the South Sumatera region. This happened especially when the momentum of the reformist group had to deal with religious authorities held by Islamic traditionalists (Peeters, 1997). Joseph Tamney in his study, reported such conditions occured 
because the reformist movement was identified with purification efforts including those carried out by Muhammadiyah in Palembang (Tamney, 1980). A similar study on purification movement was also confirmed by James L. Peacock who assessed Muhammadiyah organization in promoting to purify Islamic teachings through various social approaches (Peacock, 2016), as an alternative effort to carry out religious reforms (Peacock, 1978b).

Related to Islamic education, Ismail's research should be put into consideration. He stated that the style of madrasa education in the Residency of Palembang (South Sumatera) was more modern in nature, carried out by the Kaum Mudo (modernist) (Sukardi, 2013). Other studies that focus more on Muhammadiyah as a reform movement can be seen from Aminullah Elhady's research which shows that Muhammadiyah organization has a significant role in the national development process in education (Aminullah, 2018).

Based on previous research, this study becomes relevant and significant when investigating on Muhammadiyah education. This issue has not been investigated comprehensively so far, especially Muhammadiyah education movement in the periphery or village context. This study tries to construct the dynamics of Muhammadiyah education in South Sumatera which is experiencing a phase of awakening. Such conditions occur after social, political and religious relations have struggled during the development of Muhammadiyah education there, which also helped encourage the renewal of overall Islamic education in South Sumatera.

Muhammadiyah concerns in education has triggered the idea of Islamic reform which is increasingly massive. Interestingly, the characteristics of Islamic reform carried out by modernists in South Sumatera did not appear in urban areas where it is usually the mainstream of this organizational movement. In this context, Muhammadiyah educational movement happened in rural areas and became the basis for Islamic renewal. Such conditions are of course contrary to the style of renewal in other regions, where modernists always have a base in urban areas while traditionalists are in the periphery or rural areas. Socially, such a process occurs because of factors of Islamic renewal which occur intensively in rural areas (periphery) that undergo a process of negotiation and integration in the social community.

\section{METHOD}

This research is a qualitative study using a social history approach. The data is collected through library and documentation techniques, which come from various literature. Then the data are analyzed descriptively and interpretatively by considering social, political and religious aspects in the analysis. Besides that, in the historical approach, this research itself is a local history, so that the locus in this study is the surrounding South Sumatera region.

\section{RESULTS AND DISCUSSION}

\section{Muhammadiyah, Religiosity and Local Awakening}

Explaining the history of Muhammadiyah's inclusion in South Sumatera, we are always presented with data that the development of Muhammadiyah in Sumatera generally comes from Minang traders and merchants. This can be attributed to the first Muhammadiyah base on the island of Sumatera in West Sumatera. Therefore, it is only natural that the role of Minang traders and migrants play a role in the spread of Muhammadiyah on the island of Sumatera, including in the region of South Sumatera. Data shows that in 1916 the city of Pagaralam became the area that was first known to the existence of Muhammadiyah understandings. The entry and development of Muhammadiyah there began with the emergence of recitation groups which later formed the Muhammadiyah Branch of Pagaralam (Rasyid, 2010). 
In this context, Muhammadiyah educational movement has different characteristics. Until the end of 1938, the growth of the branch of organization Muhammadiyah in the Lampung-Palembang Residency area consisted of 35 branches of the Muhammadiyah branch, nine of which were located in the Iliran area, while 26 other branches were located in the Uluan area (Rasyid, 2010). With this distribution, it seems as if the Muhammadiyah is more rooted in the interior than in the coastal areas (Peeters, 1997). This pattern shows the Muhammadiyah there has different characteristics so this uniqueness confirms that the local revival of rural and inland areas took place first, then followed by urban areas.

The previous report on Muhammadiyah movement is not in line with study conducted by Riaz Hasan. He divided the typology of Muslim social formations in both folk Islam and high Islam, which according to each of them had different characteristics (Hassan, 2001). Islamic tradition refers to the figure of a religious leader who is considered to have authority in religious matters (Peacock, 1978), where his power base is in rural areas and rural communities (Tamney, 1980). Whereas high Islam is characterized as a puritanism movement represented by modernist Muslim scholars based in urban areas (Robert W. Hefner, 2015). Although according to Riaz, urban environmental factors have elective affinity with puritanism, so that urban communities are more free to accept modernity. But on the contrary, Muhammadiyah in South Sumatera took different steps in the typology.

The growth and increasing influence of modern Muslim movements such as Muhammadiyah and others sparked "traditionalist" Muslim clerics (Kaum Tuo) to combine forces to compensate for the Islamic modernists (Kaum Mudo). Such an effort is in order to foster Islamic traditionalists and to give the voice of the organization to traditional Islamic interests (Bush \& Fealy, 2014), and especially the pesantren system (Barton \& Fealy, 1996). Even traditionalist scholars are quite worried that Islamic modernism will seriously influence their authority and endanger their social and economic position (Beck, 2014). This condition seems to be a strong reason Muhammadiyah considers their position outside of urban areas.

Muhammadiyah's efforts in South Sumatera as a reform movement tried to provide Islamic understanding by not releasing the fact of plurality around it. Thus, according to Davies, the negotiation of Islam and local culture (as carried out by Muhammadiyah) is a form of struggle/effort to bring and bring together the norms and values of both (Davies, 2003). Islam, which is actually a form of Muslim faith, ideology and doctrine shifts when the assessment of the terms of Islam is often biased and misinterpreted. When views on Islam which only refer to historical phenomena and cultural practices that are different from religious teachings, show Islam as something that is very problematic (Douglass, 2004: 6).

In contrast, European views that see religiosity and faith are sometimes incompatible with modernity. So that looking at modern Muslims who hold Islamic principles will not be in line, because according to them there will be conflict of conflicts such as the emergence of the phenomenon of fundamentalism (Hassan, 1985) and radicalism in Islam, which emerged from the rejection of modernism (Frans \& Kocku von, 2016).

Muhammadiyah which has a spirit of renewal also takes advantage of opportunities through its education to spread the idea of ideas for renewal and purification of Islamic teachings based on the Alqur'an and Sunnah scriptures, which according to Muhammadiyah Islamic values are in line with the progress of modern times. So the clash of differences in understanding according to him is part of the dialectics and the dynamics of change.

In addition, to strengthen the existence of Muhammadiyah branches in the South Sumatera region, a number of conferences were held annually during 1931-1938, as strengthening Muhammadiyah in several regions that were still incorporated in the Southern Sumatera region, such as Kerasidenan Palembang, Bangka and Lampung. The initiation of this 
conference indicated part of the strengthening and response efforts of the high interest of Muhammadiyah members outside Java towards the Muhammadiyah organization.

Strengthening Muhammadiyah branches also discussed several religious, socio-political and educational issues. So that the steps taken by Muhammadiyah every time opening branches are always accompanied by enthusiasm to establish Islamic schools. The schools established by Muhammadiyah itself were not purely derived from the community funds, but also in the form of assistance from members, sympathizers, donors and also the subsidies of the Dutch East Indies government at that time (Almanak, 1936).

Through a more modernist and dialectical approach, not a few local people are interested in even donating property to Muhammadiyah's educational interests such as land and building endowments. The enthusiasm of the community in the development of Muhammadiyah education in South Sumatera, so that on several occasions sometimes it also brought directly to the Muhammadiyah Central Committee from Yogyakarta to attend the establishment of schools and help preach in several regions of South Sumatera. Such a pattern does not appear to be merely ceremonial, but rather to increase community sympathism with the presence of prominent leaders and central Muhammadiyah leaders. Thus it will further strengthen the existence of Muhammadiyah to be more accepted by the local community, both through its missionary movements and through Muhammadiyah education.

\section{Modernization and Style of Islamic Education}

The establishment of Muhammadiyah in Yogyakarta in 1912 with its purification and education movement, has encouraged Muslim figures in Palembang to hold reforms in the field of Islamic education as well. But until the early 1930s the intended influence did not seem to be an institutional influence, but in the form of a spirit of renewal, because the city of Palembang was still dominated by figures of the Kaum Tuo who had not been able to accept the presence of the Kaum Mudo represented Muhammadiyah. Therefore the Muhammadiyah branch itself was opened for the first time in rural areas and not in Palembang City (Sukardi, 2013).

In other words, the influence of the renewal of Islamic education in South Sumatera initiated by Muhammadiyah has not been fully accepted directly because the style of modernist understanding still has a clash of tendencies by traditionalists. Nevertheless, it needs to be explored further in the extent to which the traditionalists reject the modernist movement (Muhammadiyah). So whether the polarization (city-village) is geographically based on the position and location of the city-village, or something like that is only "mentality", because the city of Palembang (Gin, 2004) is historiographically a city with a port quite large, where Sriwijaya's royal maritime base initially relied on maritime power as an advantage, both in terms of trade, defense and government. Therefore Taufik Abdullah assessed the heterogeneity of the population as well as the opening of Palembang as a port city is a social support factor that is easier to accept the arrival of new cultures (Taufik, 1986), especially those brought by migrants from merchants and merchants anchored in the city Palembang. This kind of thing can be seen from the culture of the people of South Sumatera who are characterized by a mixture of Malay, Javanese, Arabic, Indian and Chinese.

The socio-cultural side of the people of South Sumatera is heterogeneous, but Islamic authorities in South Sumatera at that time still adhered to the sultanate and the palace. While the sultanate itself is Islamdom, a center of power that consciously engages in Islamic traditions and teachings. At least the formal form of the sultanate is a place which further opens up the possibility for the continuation of the process of Internal Islamization. While the scholars themselves are not part of the power structure. The influence of scholars is very much dependent on his ability to convince rulers. But unfortunately there were no strong ulama accompanying the sultan at that time. Because the pattern of the Palembang Sultanate 
did not follow the pattern as in Aceh, Mataram and Banten, where the ulama had an intimate relationship with the sultanate (Taufik, 1986).

Islamic authority in this era has been constructed on the dimensions of religious stratification, where traditionalists feel they have a more important role in maintaining the spirit of Islamic tradition. In the present context, authority and power are not always easily distinguished. Religious authority can take a number of forms and functions: ability (opportunity, power, or right) to define right beliefs and practices, or orthodoxy and orthopraxy, respectively; to shape and influence the views and behavior of other appropriate people; to identify, marginalize, punish or rule out irregularities, heresy and apostasy and their agents and supporters. In monotheistic religions founded on revealed scriptures, religious authority subsequently involved the ability (opportunity, power, or right) to compile and define scriptures from "authoritative" texts and legitimate methods of interpretation (Krämer, Gudrun, Schmidtke, 2006).

Therefore, it is natural that traditionalist scholars have concerns with modernists, especially the bureaucratization of religion held by traditionalist scholars is not very influential in the structural sultanate of Palembang. Muhammadiyah's presence seemed to add to the polemic of concern over the position of the traditionalist scholars who had always tried to be in the circle of Sultan Mahmud Badarudin. Observing this condition, Muhammadiyah has a more accommodating long-term interest, namely establishing education. So this is where Muhammadiyah feels it does not have to be involved in the aspect of "seizing" religious authority within the sultanate. This organization actually sees rural areas outside the city of Palembang having aspects that might be "safer" to call them conducive in strengthening their education base.

The presence of Muhammadiyah itself has initiated becoming a driving factor for renewing Islamic education in South Sumatra. The birth of several madrassas up to 1928 such as the Arabiyah, Al-Ihsan, Sjamsoel Huda, Qur'aniah and Ahliyah madrasas cannot be separated from the influence of the establishment of Muhammadiyah as a reform organization. In other words, the establishment of Muhammadiyah in South Sumatra has encouraged Muslim leaders and other Islamic movements in Palembang to hold reforms in the education sector as well.

Muhammadiyah as a modernist organization, in the era of colonialism also supported the rejection of colonialism and the challenges faced by the Western world (Allan, 1968). Such evidence of its relation to education is lessons in Muhammadiyah schools which tend to inflame the spirit of anti-colonialism, where teachers often convey about freedom and independence accompanied by views defending homeland and religion. Uniquely, precisely the existence of colonialism itself has driven the acceleration of Islamization. This condition has become an alternative social effort by scholars and Islamic movements including Muhammadiyah to further strengthen the private Islamic community through education and discipline. Muhammadiyah encouraged the revival of the people through Islamic education which emphasized aspects of rationality and revival of thinking. This is what encourages Muhammadiyah education in South Sumatera to be assessed as part of the "trend" for renewing Islamic education that has already occurred in Java. Realizing the political situation of the Indies in South Sumatera had become a turning point for Muhammadiyah emphasizing the importance of the awakening of the ummah through education.

The backwardness and oppression of the colonial era was traumatic for the people (Rahman, 2016), so it was very clear in the early era of Muhammadiyah in South Sumatera that it showed a pattern that referred to the strengthening of the people's awakening against colonialism. The strong influence of the political situation at that time has reinforced the 
position of Muhammadiyah to fight for the aspirations of the people under pressure from the Dutch.

The activities of Islamic organizations including Muhammadiyah began to respond back to efforts to weaken Islam by the Dutch by instilling resistance through religious awareness. Muhammadiyah, for example, appears as a leading role in the renewal of Islamic education and it also responds to people's aspirations for the presence of more enlightening and exciting Islamic education. The desire of the people to crave education which is able to keep up with the education of the Dutch system has long been expected, but until the 1920s the condition of public education was still far from the quality of Dutch education. This condition was mentioned by Ismail because it was caused by the uneven awareness of the need for education for their children.

The Dutch were unable to fulfill the educational aspirations in each region in South Sumatera. Until 1936 the Muhammadiyah college received recognition by the Dutch education inspector at that time Inspecteur van Onderwijs and Hoofdschool Opziener. In this way Muhammadiyah has the right to use the name Holland Indlandsch School (HIS) for its school and the only Islamic college in the city of Palembang whose teaching is the same as the HIS Government.

Unlike the colonial era, the post-independence era such as in the 1950s, Muhammadiyah increasingly moved to call it not confined. At that time, in Indonesia itself in the 1950s there was a democratic, seemingly democratic political configuration on the surface. In such a configuration it appears that the state began to play its constitutional role (Chandra, 2015). However, the differences in politics, ideology and cultural settings have brought about a democratic atmosphere in conflict and competition that is not only limited to ideology but rather a contestation of roles in the public sphere.

Although there are a few people in South Sumatera who have enjoyed democracy, Islamic education in South Sumatera cannot be separated from the dynamics of contestation in public space. Moreover, in 1957 the convening of the ulama council in Palembang gave birth to the formulation of opposition to communism and calls for Islamic unity initiated by Masyumi, but in fact the conference did not fully unite Muslims in several respects. NU itself as a withdrawal Islamic organization did not send its delegation in the conference (Chandra, 2015). Because of the feud between NU and Masyumi which often had differences of opinion, especially in political views. Although it did not find a meeting point, the conference had given birth to an agreement to establish an Islamic university foundation to strengthen Islamic education in South Sumatera. Muhammadiyah itself was very supportive of the initiation of the establishment of Islamic college foundations which later became the forerunner of the establishment of IAIN Raden Fatah which later changed to UIN Raden Fatah in 2015.

\section{Muhammadiyah and the Awakening of Islamic Education Identity in South Sumatera}

Muhammadiyah education as an identity for Islamic education in South Sumatera is not independent. That there begins with the struggle of religious understanding and the widespread rise of Islam. Indeed, it must be acknowledged even though the rise and renewal of Islamic education in South Sumatera was part of the influence of overall Islamic reform in the archipelago, but the Jawasentris narrative always did not necessarily occur for Muhammadiyah in South Sumatera (Chandra, 2015). The religious dynamics and political situation in several regions in South Sumatera and in Palembang have been a significant influence on the identity of Muhammadiyah as a reformer of Islamic education there. In other words, Muhammadiyah education in South Sumatera is indeed much influenced by the national context, but it cannot be simplified that regions such as South Sumatera follow the flow of political, religious and social changes in society nationally (Petters, 1997). 
Muhammadiyah not only developed naturally, but also was so quick to expand its educational and missionary activities, by establishing various branches and branches in each region. This is always accompanied by the establishment of educational institutions in the region. Muhammadiyah's education was known to be quite positive among the people, even with the Dutch government starting to recognize one by one Muhammadiyah schools as HIS which not only taught religious lessons, but also the content of general lessons was also taught. The success of Muhammadiyah in its education must be recognized if in the 1930s Muhammadiyah grew. One advantage possessed by Muhammadiyah is the national network and the role of the center or other regions that can contribute to other regions (Sukardi, 2013).

Based on the previous descriptions, there are several factors that influence Muhammadiyah renewal of Islamic education in South Sumatera, namely; First, awareness of renewal of Islamic education in South Sumatera because of the form of renewal of Islam in the country. Apart from the latent efforts to reform and revive the world of Islam, also in Indonesia this happened because of the return of the Hajj group to the homeland. Martin assessed that the ideas of the pilgrims who had an impact on the influence of Islam in Arabia had filled new spaces for Islam in Indonesia (Bruinessen, 2012). Especially the influence of the global Islamic view of Indonesian pilgrims on local Islam (Putuhena, 2007). Although there will be clashes and tensions in the future, so that they describe the forms of turmoil, conflict and friction that occur in a dialectical process in the community both in ideological, cultural and social aspects.

Second, awareness in the community of the importance of education which was originally still considered partially, began to be realized the importance of education for their children. Especially the awareness that backwardness and occupation has made them more retarded. The fact is that the need for good education is beginning to be seen in almost every region hoping for an education like a Dutch school that has better quality. This is because educational institutions, especially existing Islamic education, are still of a high quality, especially in the aspects of learning and facilities that are still minimal.

Third, colonialism and underdevelopment in all fields are other factors which increasingly encourage the rise of awareness of Muslims. The acceleration of Islamization locally also contributed to Muhammadiyah's role in conducting tabligh in the form of $d a^{\prime} w a h$, associations, congresses and strengthening branches, to reinforce the power of Islam there. Although actually such conditions are also closely related to the colonial politics that were responded to by the Palembang sultanate and Islamic organizations in maintaining the palace's strong influence. Because the palace itself was a symbol of Islam in the Palembang city which was used by the Dutch in maintaining political influence in South Sumatera.

Fourth, the revival of the village, especially in the Uluan (inland) section, has become a local phenomenon which has indicated that Islamic reform in South Sumatera does not necessarily follow the pattern in other regions. Urban-peripheral polarization has formed a socio-religious contestation that shows religious identity by Muhammadiyah. Renewal efforts are carried out through educational activities, discussion and efforts to penetrate both political, social and community involvement. In these conditions, Muhammadiyah has an advantage, through the village and the village, Muhammadiyah has grown more fertile than urban areas which are still strong in the circle of traditionalists.

In general, Muhammadiyah underwent a phase of negotiation through these four conditions so that the construction of Muhammadiyah as the identity of Islamic education in South Sumatera could be confirmed. The renewal of Islamic education conducted by Muhammadiyah did not only occur in the period before independence but also occurred after independence until the 1950s. If prior to independence, from the $1920 \mathrm{~s}$ to the $1940 \mathrm{~s}$, Muhammadiyah's educational reforms were ideological-normative which was influenced by 
the situation of colonial politics and religiosity of the Sumsel community. A condition that was different from the period after independence until 1956 which was more likely to be accommodative-pluralist. Penetration of Muhammadiyah's efforts in reaching urban areas through the development of its education.

\section{CONCLUSION}

The arrival of Muhammadiyah provided a new map of the Islamic movement in South Sumatera. Especially in the field of Islamic education, although at the same time there have been models and systems of Islamic education such as those of the Alawiyyin, Sayyidin, Nahdhatul Ulama and the public. Thus the presence of Muhammadiyah is part of the dynamics of Islamic education there. The unique presence of Muhammadiyah precisely colored the renewal of Islamic education in South Sumatera. In other words, the common thread that will be drawn is the renewal of Islamic education, which is a bit of Islamic reform in Indonesia, and also provides a separate chapter for Muhammadiyah, especially in the Southern Sumatera region and Palembang city.

The construction of Muhammadiyah education as the identity of Islamic education in South Sumatera is emphasized through historical tracking which reveals the fact that the relationships surrounding Muhammadiyah's educational journey have influenced polarization which is sometimes conflict, contestation and sometimes naturally integrated. Building such negotiations forming ideological, religious, social and political relations is an important part of the dynamics of Muhammadiyah education. Although the idea of Muhammadiyah's educational reform has an ideological-normative style, it tends to continue to modernize in terms of institutions, curriculum and its role in the community.

Muhammadiyah educational movement developed in South Sumatera because of several reasons. Historically, the Dutch colonial did not provide access to education for people in rural or village areas. Another reason was that the relationship between the sultanate and Ulama had no good relationship which trigger Muhammadiyah to build and develop education in or village areas. Muhammadiyah educational movement could developed well in South Sumatera because of several supporting factors namely: Muslim awareness after they conducted pilgrimage to Makkah, social awareness to prioritize education and in support to national development for education.

\section{BIBLIOGRAPHY}

Abuza, Z. (2006). Political Islam and violence in Indonesia. Political Islam and Violence in Indonesia. London: Routledge. https://doi.org/10.4324/9780203969250

Allan, S. (1968). Islam in Indonesian Politics. Asian Survey, 8(16), 101-117.

Almanak. (1936). Almanak Muhammadiyah. P.B. Mubammadiyah, pp. 68-87.

Aminullah, E. (2018). Islamic Reform Movement In Indonesia: Role Of Muhammadiyah In Social Empowerment. International Journal of Academic Research in Business and Social Sciences. https://doi.org/10.6007/ijarbss/v7-i8/3234

Barton, G., \& Fealy, G. (1996). Nabdlatul Ulama, Traditional Islam and Modernity in Indonesia. Clayton: Monash Asia Institute.

Beck, H. L. (2014). The contested state of Sufism in Islamic Modernism: The case of the Muhammadiyah movement in twentieth-century Indonesia. Journal of Sufi Studies. https:// doi.org/10.1163/22105956-12341269

Bruinessen, M. Van. (2012). Kitab Kuning, Pesantren dan Tarekat. Yogyakarta: Gading Publishing. Bush, R., \& Fealy, G. (2014). The political decline of traditional Ulama in Indonesia: The state, Umma and Nahdlatul Ulama. Asian Journal of Social Science. https://doi.org/10.1163/15685314-04205004 
Chandra, R. (2015). Kontestasi Politik di Palembang 1950-1970: Dinamika Politik Islam dari Liberal Sampai Transisi Menuju Orde Baru. Yogyakarta: IDEA Press.

Davies, J. R. (2003). Islam, law, and equality in Indonesia: An anthropology of public reasoning. Islam, Law, and Equality in Indonesia: An Antbropology of Public Reasoning. https://doi.org/10.1017/CBO9780511615122

Douglass, S. L. (2004). Defining islamic education: differentiation and applications. Comparative Education.

Formichi, C. (2012). Islam and the Making of the Nation: Kartosuwiryo and Political Islam in 20th Century Indonesia. https://doi.org/10.1163/9789004260467

Frans, W., \& Kocku von, S. (Eds.). (2016). Making Religion: Theory and Practice in the Discursive Study of Religion. Boston: Brill.

Gin, O. K. (2004). SOUTHEAST ASIA A Historical Encyclopedia, from Angkor Wat to East Timor. ABC Clio. https://doi.org/10.1017/CBO9781107415324.004

Hassan, R. (1985). Islam dari Konservatisme Sampai Fundamentalisme. Jakarta: Rajawali Press.

Hassan, R. (2001). Imagining Religion: Self-Images of Islam in the Late Twenthieth Century. Asian Studies Review, 25(2), 131-151.

Krämer, G., \& Schmidtke, S. (2006). Speaking for Islam. Religious Authorities in Muslim Societies. (G. Krämer \& S. Schmidtke, Eds.), Brill. London: Brill.

Nakamura, M. (1983). Bulan Sabit Muncul di Balik Pohon Beringin: Studi Tentang Pergerakan Muhammadiyah di Kotagede Yogyakarta. Yogyakarta: Gadjah Mada University Press.

Noer, D. (1996). Gerakan Modern Islam di Indonesia 1900-1942. Jakarta: LP3ES.

Peacock, J. L. (1978a). Muslim Puritan: reformist psychology in Southeast Asian Islam. Berkeley: University of California.

Peacock, J. L. (1978b). Purifying the Faith: The Mubammadiyah Movement in Indonesia Islam. Benjamin/Cummings Publishing Company.

Peacock, J. L. (2016). Gerakan Muhammadiyah Memurnikan Ajaran Islam di Indonesia. Yogyakarta: Suara Muhammadiyah.

Peeters, J. (1997). Kaum Tuo dan Kaum Mudo: Perubaban Religius di Palembang 1821-1942. Jakarta: INIS.

Putuhena, M. S. (2007). Historiogafi Haji Indonesia. Yogyakarta: LKiS.

Rahman, A. (2016). Reformasi dan Arah Pembaharuan Pendidikan Islam. Literasi, 7(02), 7588.

Rasyid, A. (2010). Sejarah Mubammadiyah Sumatera Selatan. Palembang: Tunas Gemilang.

Robert W. Hefner. (2015). Making Modern Muslims: The Politics of Islamic Education in Southeast Asia. Asia Ethnology Journal. https://doi.org/10.1038/sj.npp.1300278

Setiawan, F. (2016). Genealogi dan Modernisasi Sistem Pendidikan Mubammadiyah 1911-1942. : Semesta Ilmu.

Sukardi, I. (2013). Madrasah dan Pergolakan Sosial Politik di Kerasidenan Palembang Tabun 19251942. Tunas Gemilang.

Tamney, J. (1980). Modernization and Religious Purification: Islam in Indonesia. Review of Religious Research, 207-218. https://doi.org/10.2307/3510661

Taufik, A. (1986). Beberapa Aspek Perkembangan Islam di Sumatera Selatan. In K. H. O. Gadjahnata \& S. S. Edi (Eds.), Masuk dan Berkembangnya Islam di Sumatera Selatan. Jakarta: UI Press. 